\title{
RISK MANAGEMENT OF ALLERGENIC FOOD INGREDIENTS IN HOSPITALITY ${ }^{1}$
}

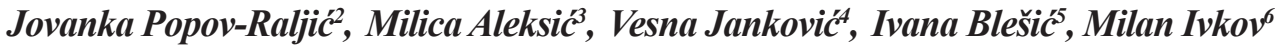

\section{Summary}

Food allergens have appeared in the last two decades as a concealed form of threat which significantly endangers public health, and their labelling on food products, drinks, and non pre-packed gastro-products is clearly defined with legal regulations.

In practice, the chemical risk management is faced with several unexpected problems. Some of them are declarations or statements about allergenic ingredients, where a nutritional allergen that the food contains is labelled with an unusual name, or similar products from different manufacturers where one is safe and the other contains allergens.

A hospitality facility which deals with production and distribution of unpackaged foods should, in addition to a developed HACCP concept and standardized recipes for food preparation, prepare a detailed, precise, and clearly defined plan for management of chemical risks.

Key words: Allergenic food ingredients, risk management, hospitality, food safety

JEL: $118, L 66, Q 18$

1 This paper is a part of the short-term project of the Province - Vojvodina, Novi Sad, named: Agricultural, food and gastro-products in the function of tourism development in Vojvodina directed to authentic and healthy and safe food, under the number: 142-451-2669/2017.

2 Jovanka Popov-Raljić Ph.D., Full Professor, University of Novi Sad, Faculty of Science, Department of Geography, Tourism and Hotel Management, Trg Dositeja Obradovića 3. 21000 Novi Sad, Serbia, Phone: +381 21485 2884, E-mail: jovankaraljicpopov@gmail.com

3 Milica Aleksić, M.A., Assistant, University of Novi Sad, Faculty of Science, Department of Geography, Tourism and Hotel Management, Trg Dositeja Obradovića no. 3. 21000 Novi Sad, Serbia, Phone: +38121 485 2884, E-mail: aleksic.milica75@gmail.com

4 Vesna Janković Ph.D., Institute of Meat Hygiene and Technology (INMES), Department of Microbiological and Molecular - Biological Research, Kacanskog street no. 13, Belgrade, Serbia, Phone: +381 112650 655, E-mail: vesna.jankovic@inmes.rs

5 Ivana Blešić Ph.D., Associate Professor, University of Novi Sad, Faculty of Science, Department of Geography, Tourism and Hotel Management, Trg Dositeja Obradovića no. 3. 21000 Novi Sad, Serbia, Phone: +381 21485 2884, E-mail: ivana.blesic@gmail.com

6 Milan Ivkov Ph.D., University of Novi Sad, Faculty of Science, Department of Geography, Tourism and Hotel Management, Trg Dositeja Obradovića no. 3. 21000 Novi Sad, Serbia, Phone: +381 21485 2842, E-mail: ivkov.milan@gmail.com

EP 2017 (64) 3 (1263-1276) 


\section{Introduction}

Allergenic food ingredients, food allergies and intolerance present a food safety risk that has been a subject of great polemics lately. In European countries it is stated that the prevalence of food allergies in the total population is present $1-3 \%$ among adults and $4-6 \%$ among children, whereas in the USA this number increases to 9 million adults ( $4 \%$ of adult population) and 6 million or $8 \%$ of children under 18 (Branum, Lukacs, 2008; De Blok et al., 2007). Considering the fact that the percentage of population allergic to certain foodstuffs is on the increase, it is of great importance that the staff of hospitality facilities are informed about food allergies and the methods of preventing allergic reactions (Mandabach et al., 2005). Advantages of providing correct food and beverages service to consumers with food allergies include increasing sales, respect and loyalty of consumers (Kwon et al., 2013). According to Abbot et al., 2007, research in the world indicates the lack of knowledge with employees in hospitality about risks of allergenic food ingredients. The worldwide research also indicate the fact that approximately $70 \%$ of employees in hospitality has not had an opportunity to be trained and educated about food allergens, allergenic food ingredients or allergen management (Ahuja, Sicherer, 2007; Choi, Rajagopal, 2013).

According to the Regulation on declaration, labeling and advertizing food (Pravilnik o deklarisanju, označavanju i reklamiranju hrane (,Sl.glasnik RS“ broj 19/2017) there are 14 food ingredients which can cause allergic reactions or intolerance, and for 11 of the mentioned ingredients there are also suggested reference doses (Allergen bureau, 2012). Their distribution and severity of consequences of food and derivatives allergies (Fooddrink Europe, 2013) are shown in Table 1.

Table 1. Allergenic food ingredients and their distribution

\begin{tabular}{|c|c|c|}
\hline $\begin{array}{l}\text { Allergens and their reference doses } \\
\qquad(\mathrm{mg})\end{array}$ & Distribution and severity & $\begin{array}{l}\text { Certain derivatives and food } \\
\text { that contain allergens which can } \\
\text { provoke allergic reactions }\end{array}$ \\
\hline $\begin{array}{l}\text { Cereals that contain gluten } \\
\text { (wheat, rye, oats, barley, spelt, kamut } \\
\text { and varieties obtained by crossing } \\
\text { them, with the exception of: wheat } \\
\text { based glucose syrup and dextrose, wheat } \\
\text { maltodextrin, glucose syrups based } \\
\text { on barley and cereal destilates or } \\
\text { ethyl alcohol of agricultural origin } \\
\text { for the production of strong alcoholic } \\
\text { beverages obtained from cereals) }\end{array}$ & $\begin{array}{l}\text { Celiac disease or gluten } \\
\text { intolerance. } \\
\text { Allergens from cereals } \\
\text { can cross-react with pollen } \\
\text { allergens. }\end{array}$ & $\begin{array}{ll}\checkmark & \text { Flour } \\
\checkmark & \text { Starch } \\
\checkmark & \text { Bran } \\
\checkmark & \text { Melba toast } \\
\checkmark & \text { Bread, breadcrumbs } \\
\checkmark & \text { Grits } \\
\checkmark & \text { Cous-cous } \\
\checkmark & \text { Hydrolysed vegetable protein } \\
& \text { protein povrća (if originates } \\
& \text { from wheat) }\end{array}$ \\
\hline
\end{tabular}




\begin{tabular}{|c|c|c|}
\hline Eggs and egg products & $\begin{array}{l}\text { Egg allergy is common with } \\
\text { children, but more than a half } \\
\text { of children outgrow this allergy } \\
\text { by their third year of age. } \\
\text { Some individuals may } \\
\text { experience anaphylactic } \\
\text { reactions }\end{array}$ & $\begin{array}{l}\checkmark \quad \text { Powdered eggs, dried eggs or } \\
\quad \text { pasteurized eggs } \\
\checkmark \quad \text { Albumin } \\
\checkmark \quad \text { Egg glaze } \\
\checkmark \quad \text { Mayonnaise } \\
* \text { Note: Lysozyme (produced from } \\
\text { eggs), which is used in wines, } \\
\text { and albuminhave small chances } \\
\text { of causing a reaction.However, } \\
\text { when lysozyme is used for other } \\
\text { purposes, it can cause unwanted } \\
\text { reactions. }\end{array}$ \\
\hline $\begin{array}{l}\text { Milk and dairy products including } \\
\text { lactose } \\
\text { Except: whey used to produce destilates } \\
\text { or ethyl alcohol of agricultural origin } \\
\text { for strong alcoholic beverages, lactitol. } \\
\text { Reference dose }=\mathbf{0 , 1} \mathbf{~ m g}\end{array}$ & $\begin{array}{l}\text { Allergy to cow's milk is the } \\
\text { most common allergy with } \\
\text { younger children and it is } \\
\text { present with } 2-7 \% \text { babies } \\
\text { under one year of age. About } \\
87 \% \text { of children grow out of } \\
\text { this allergy by their third year } \\
\text { of age. } \\
\text { There is a large degree of cross- } \\
\text { reactivity between cow's milk } \\
\text { and milk of other mammals, } \\
\text { such as sheep, goats or buffalo. }\end{array}$ & $\begin{array}{ll}\checkmark \checkmark & \text { Whey } \\
\checkmark & \text { Casein } \\
\checkmark & \text { Milk powder } \\
\checkmark & \text { Lactose } \\
\checkmark & \text { Butter, cheese, creams, } \\
& \text { yoghurt }\end{array}$ \\
\hline $\begin{array}{l}\text { Allergens and their reference doses } \\
(\mathbf{m g})\end{array}$ & Distribution and severity & $\begin{array}{l}\text { Certain derivatives and food } \\
\text { that contain allergens which can } \\
\text { provoke allergic reactions }\end{array}$ \\
\hline Crustaceans (crab & $\begin{array}{l}\text { Allergy to crabs is very } \\
\text { common. People who are } \\
\text { sensitive can react to different } \\
\text { kinds of crustaceans. } \\
\text { Crustaceans often cause severe } \\
\text { reactions, and some people } \\
\text { may react to vapour produced } \\
\text { during cooking. }\end{array}$ & $\begin{array}{ll}\checkmark & \text { Gastro-products made of } \\
& \text { crustaceans } \\
\checkmark & \text { Salads } \\
\checkmark & \text { Dippings } \\
\checkmark & \text { Clear and thick soups }\end{array}$ \\
\hline Reference dose $=1 \mathrm{mg}$ & & \\
\hline
\end{tabular}




\begin{tabular}{|c|c|c|}
\hline $\begin{array}{l}\text { Shellfish and other mollusks and their } \\
\text { products } \\
\text { Reference dose is not determined }\end{array}$ & $\begin{array}{l}\text { Allergies to shellfish can cause } \\
\text { reactions even in people who } \\
\text { are sensitive to protein in fish } \\
\text { products. } \\
\text { Isolated protein which } \\
\text { causes the stated reactions is } \\
\text { called tropomyosin and it is } \\
\text { contained in all shellfish, and/ } \\
\text { or parvalbumin which is found } \\
\text { in codfish. } \\
\text { The research has shown that } \\
\text { trpomyosin is a cross-reactive } \\
\text { allergen both in crustaceans } \\
\text { and mollusks }\end{array}$ & $\begin{array}{ll}\checkmark & \text { Hot dishes made of shellfish } \\
& \text { and mollusks } \\
\checkmark & \text { Salads } \\
\checkmark & \text { Dippingd } \\
\checkmark & \text { Clear and thick soups }\end{array}$ \\
\hline $\begin{array}{l}\text { Fishery products } \\
\text { (codfish, shark, } \\
\text { salmon, tuna) } \\
\text { With the exception of fish gelatin used } \\
\text { as a carrier for vitamines, fish gelatin } \\
\text { or isinglass for clarification of beer and } \\
\text { wine } \\
\qquad \text { Reference dose }=\mathbf{0 , 1} \mathbf{~ m g}\end{array}$ & $\begin{array}{l}\text { Fish allergy is more common } \\
\text { in adults than in children, but it } \\
\text { can often be very severe and } \\
\text { cause an anaphylactic shock. } \\
\text { All major fish allergies can } \\
\text { cross react in the sense of their } \\
\text { allergenicity and no fish is safe } \\
\text { for perople allergic to it. }\end{array}$ & $\begin{array}{l}\checkmark \text { All kinds of fish } \\
\checkmark \text { Fish extracts } \\
\checkmark \text { Fish sauces } \\
\checkmark \text { Fish oils } \\
\checkmark \text { Worcester sauce } \\
\checkmark \text { Omega-3 oils } \\
\text { * Note: fish gelatin used for } \\
\text { vitamins and flavours, and fish } \\
\text { gelatine used in beer, wine and } \\
\text { cider production have little chance } \\
\text { of causing allergic reactions. }\end{array}$ \\
\hline $\begin{array}{l}\text { Allergens and their reference doses } \\
\text { (mg) }\end{array}$ & Distribution and severity & $\begin{array}{l}\text { Certain derivatives and food } \\
\text { that contain allergens which can } \\
\text { provoke allergic reactions }\end{array}$ \\
\hline $\begin{array}{l}\text { Soy and soy products } \\
\text { With the exception of completely refined } \\
\text { soybean oil and fat, natural mixtures } \\
\text { with tocopherols (E306), natural } \\
\text { D-alpha tocopherol acetate, D-alpha } \\
\text { tocopherolsuccinate originated in } \\
\text { soy, phytosterol and phytosterol esters } \\
\text { isolated from soybean oil }\end{array}$ & $\begin{array}{l}\text { Allergy to soybeans is common } \\
\text { in children, but they often } \\
\text { grow out of it by the age of } \\
\text { two. Adults are sometimes } \\
\text { affected with this allergy. The } \\
\text { symptoms are usually mild, } \\
\text { and anaphylactic reactiona are } \\
\text { very rare. } \\
\text { An allergic cross-reactivity of } \\
\text { soybeans and other legumes, } \\
\text { including peanuts is possible, } \\
\text { and there are reports on the } \\
\text { cross-reactivity of soybeans } \\
\text { and cow's milk. }\end{array}$ & $\begin{array}{ll}\checkmark & \text { Soy flour } \\
\checkmark & \text { Tofu from soybeans } \\
\checkmark & \text { Soy protein isolates } \\
\checkmark & \text { Soy protein concentrate } \\
\checkmark & \text { Soybean formula for infants } \\
\checkmark & \text { Soy sauce }\end{array}$ \\
\hline
\end{tabular}




\begin{tabular}{|c|c|c|}
\hline Lupin and lupin products & $\begin{array}{l}\text { Lupin, or lupine, is a genus in } \\
\text { the legume family. } \\
\text { Lupin flour is rich in protein, } \\
\text { especially in lysine, an essential } \\
\text { aminoacid. }\end{array}$ & $\begin{array}{ll}\checkmark & \text { Bread } \\
\checkmark & \text { Pastry } \\
\checkmark & \text { Dippings } \\
\checkmark & \text { Stews } \\
\checkmark & \text { Pasta } \\
\checkmark & \text { Meat products-sausages }\end{array}$ \\
\hline Peanut and peanut & $\begin{array}{l}\text { A significant number of people } \\
\text { allergic to peanutsare allergic } \\
\text { to other nuts as well, and they } \\
\text { also have an allergic cross- } \\
\text { reaction with other legumes, } \\
\text { such as soybeans and lupin. } \\
\text { Thermal treatment, especially } \\
\text { baking, increases the } \\
\text { allergenicity of peanuts. }\end{array}$ & $\begin{array}{ll}\checkmark & \text { Non-refined, cold-pressed } \\
& \text { peanut oil } \\
\checkmark & \text { Peanut butter } \\
\checkmark & \text { Peanut flour } \\
\checkmark & \text { Different peanut protein } \\
& \text { products } \\
\checkmark & \text { Refined peanut oil }\end{array}$ \\
\hline $\begin{array}{l}\text { Allergens and their reference doses } \\
(\mathbf{m g})\end{array}$ & Distribution and severity & $\begin{array}{l}\text { Certain derivatives and food } \\
\text { that contain allergens which can } \\
\text { provoke allergic reactions }\end{array}$ \\
\hline $\begin{array}{l}\text { Nuts: almonds, hazelnuts, walnuts, } \\
\text { cashews, pecans, Brazilian nuts, } \\
\text { pistachios, macadamia nuts and } \\
\text { Queensland nuts and their products. } \\
\text { Except: nuts used in the production } \\
\text { of destilates and ethyl alcohol of } \\
\text { agricultural origin for strong alcoholic } \\
\text { beverage }\end{array}$ & $\begin{array}{l}\text { Almonds, hazelnuts, walnuts, } \\
\text { cashews, pecans, Brazilian } \\
\text { nuts, pistachios, macadamia } \\
\text { nuts and Queensland nuts } \\
\text { and their products - are } \\
\text { very common causes of } \\
\text { allergies and they can cause } \\
\text { anaphylactic reactions in } \\
\text { people who are susceptible to } \\
\text { allergies. }\end{array}$ & $\begin{array}{ll}\checkmark & \text { Butter made of nuts } \\
\checkmark & \text { Pralines (hazelnut) } \\
\checkmark & \text { Marcipan } \\
\checkmark & \text { Almonds paste } \\
\checkmark & \text { Walnut oil } \\
\checkmark & \text { Worcester sauce (some brands } \\
& \text { contain walnuts) }\end{array}$ \\
\hline $\begin{array}{l}\text { Celery and celery products } \\
\text { Reference dose }=\text { not determined }\end{array}$ & $\begin{array}{l}\text { Celery is a common cause of } \\
\text { allergies in Europe. } \\
\text { The symptoms range from } \\
\text { mild to severe (anaphylaxis). } \\
\text { In Germany, } 2.5 \% \text { of } \\
\text { population suffer from this } \\
\text { form of food allergy, whereas it } \\
\text { is not common in Great Britain. }\end{array}$ & $\begin{array}{l}\checkmark \quad \text { Celery powder } \\
\checkmark \quad \text { Celery seeds } \\
\text { * Note:celery leaves and seed } \\
\text { oil most commonly do not cause } \\
\text { allergic reactions. }\end{array}$ \\
\hline
\end{tabular}




\begin{tabular}{|c|c|c|}
\hline $\begin{array}{l}\text { Mustard and mustard products } \\
\text { Reference dose }=\mathbf{0 , 0 5} \mathbf{~ m g}\end{array}$ & $\begin{array}{l}\text { Mustard allergy is not common } \\
\text { in Great Britain, however, it } \\
\text { is common in France, where } \\
\text { severe reactions, incuding } \\
\text { anaphylaxix, have been } \\
\text { reported. }\end{array}$ & $\begin{array}{ll}\checkmark & \text { Mustard paste } \\
\checkmark & \text { Mustard seed } \\
\checkmark & \text { Mustard leaves } \\
\checkmark & \text { Mustard flour } \\
\checkmark & \text { Mustard powder } \\
& \\
* & \text { Note: mustard oil and mustard } \\
\text { seed oil most commonly do not } \\
\text { cause allergic reactions. }\end{array}$ \\
\hline $\begin{array}{l}\text { Allergens and their reference doses } \\
\text { (mg) }\end{array}$ & Distribution and severity & $\begin{array}{c}\text { Certain derivatives and food } \\
\text { that contain allergens which can } \\
\text { provoke allergic reactions }\end{array}$ \\
\hline $\begin{array}{l}\text { Sesame seed and sesame products } \\
\text { Reference dose }=\mathbf{0 , 2} \mathbf{~ m g}\end{array}$ & $\begin{array}{l}\text { Sesame allergy is most } \\
\text { pronounced among inhabitants } \\
\text { of Israel, and it is increasingly } \\
\text { common in Great Britain } \\
\text { as well and it can cause } \\
\text { severe reactions including } \\
\text { anaphylaxis. } \\
\text { There is a cross-reactivity } \\
\text { between nuts and sesame } \\
\text { seeds. }\end{array}$ & $\begin{array}{ll}\checkmark & \text { Sesame seed } \\
\checkmark & \text { Sesame oil } \\
\checkmark & \text { Sesame paste } \\
\checkmark & \text { Tahini } \\
\checkmark & \text { Hummus } \\
\checkmark & \text { Halvah }\end{array}$ \\
\hline $\begin{array}{l}\text { Sulfur - dioxide and sulfites } \\
\text { *over } 10 \mathrm{mg} / \mathrm{kg} \text { or } 10 \mathrm{mg} / \mathrm{l} \text { expressed } \\
\text { as } \mathrm{SO} 2\end{array}$ & $\begin{array}{l}\text { Supplements of sulfites in } \\
\text { wines are associated with } \\
\text { causing asthmatic reaction } \\
\text { in sensitive individuals, most } \\
\text { commonly people who suffer } \\
\text { from asthma. } \\
\text { Symptoms can be severe with } \\
\text { a minority of people suffering } \\
\text { from asthma. }\end{array}$ & $\begin{array}{ll}\checkmark & \text { E220 sulfur dioxide } \\
\checkmark & \text { E221 sodiumsulfite } \\
\checkmark & \text { E222 sodium bisulfite } \\
\checkmark & \text { E223 sodium metabisulfite } \\
\checkmark & \text { E224 potassium metabisulfite } \\
\checkmark & \text { E226 calcium sulfite } \\
\checkmark & \text { E227 calcium bisulfite } \\
\checkmark & \text { E228 potassium bisulfite } \\
& \\
\text { Sulfur dioxide and sulfites are } \\
\text { used as preservatives - dried fruit } \\
\text { and vegetables, non-alcoholic } \\
\text { beverages, fruit juices, fermented } \\
\text { beverages such as wine, beer, } \\
\text { ciders, sausages and burgers. }\end{array}$ \\
\hline
\end{tabular}

Source: Authors' presentation according to the Regulation on declaration, labeling and advertizing food (Pravilnik o deklarisanju, označavanju i reklamiranju hrane (,Sl.glasnik RS“ broj 19/2017), Allergen bureau, 2012. and Fooddrink Europe, 2013.

Besides 14 common nutritive allergens which must be labeled, consumers often complain on allergies and intolerances to other types of food such as honey, tomato, kiwi, oranges, rice, apples and others (Zurzolo et al., 2012).

\section{Management of food allergens}

Application of basic principles of food safety management in hospitality grounded on understanding of nutritive allergies and food production processed leads to the development 
of a system which can support production of food which contains and does not contain a certain allergen in conditions where the risk for a consumer is reduced to a minimum (Alldrick, 2006). The modern approach to food safety management in hospitality is most often based on a need to prevent a risk and reduce it to an acceptable level, before it actually appears in practice. Allergies and intolerances to food ingredients which are contained in gastro-products are one of the safety risks which are widely considered in food industry. The general opinion is that in case of allergenic food ingredients it is not realistic to talk about the possibilities of zero risk (Kroes et al., 2000; Madsen et al., 2012), which is why it is extremely important to set standards in hospitality which will reduce this risk to a minimum. Precisely defined and consistent standards related to allergen safety management lead to a consistent and sustainable safety management in food industry (Hattersley et al., 2014) but also in the production of gastro-products in hospitality facilities. Allergenic food ingredients can pose a risk in two situations, when they directly enter the organism individually or as ingredients of a gastro-product or with a cross-contamination of non-allergenic foodstuffs with the allergenic ones during the food production process (Madsen et al., 2009).

The illustrative image (Picture 1.) shows the basic critical elements in estimating and management of allergenic risks (Fooddrink Europe, 2013).

Picture 1. Critical elements in estimating and management of allergenic risks in hospitality

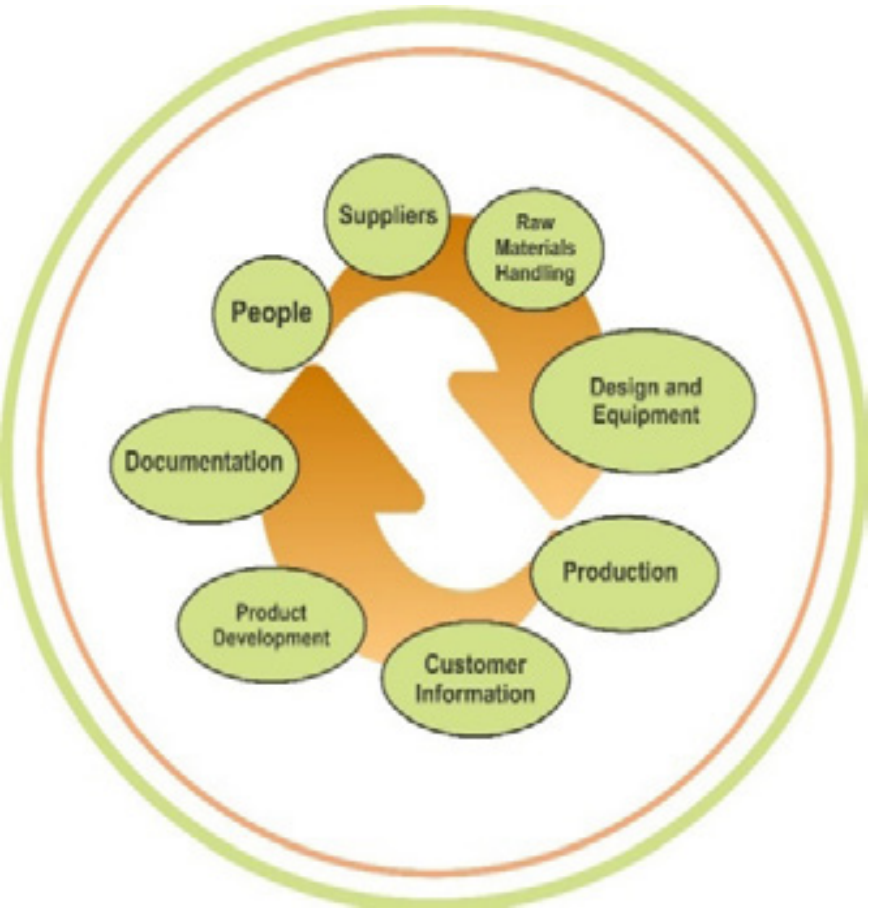

Source: Modified according to Fooddrink Europe, 2013.

People - the communication of risks or the process of exchanging information between the interested parties about the nature, intensity and importance of risk control is extremely important for the food safety system, because how we understand the risk affects the 
perception of specific risks (allergenic food ingredients) of an individual or a group.

Knowledge and behaviour of management and employees and their perception of the importance of allergenic food ingredientsof risk management have a significant effect on the outcomes of allergenic reactions in hospitality facilities (Lee, Sozen, 2016). Concretely, employees in hospitality facilities have a critical role in reducing the unwanted effects of allergenic food ingredients and their job requires specialized knowledge based on HACCP principles in risk management and implementation of safety protocols of allergens management (Aleksić, Popov-Raljić, 2015; Dupuis et al., 2016).

A supply chain - the control of allergens in a supply chain requires close connection and good communication with suppliers with clearly defined needs and requirements. A food distributor and supplier must be confidential, constant and consistent, with determined standards and developed professional awareness of potential risks which can be caused by mistaking a product of similar packaging and different suppliers. Examples of good production practice are questionnaires about being acquainted with health and safety risks and taken measured during the food distribution filled by suppliers during the application process, regardless having a well elaborated HACCP plan.

Handling raw materials - reception and storage of food ingredientsmust be a strictly controlled part of the food safety system. Although common procedures referring to security and sustainability of health and safety quality of food largely secure this potential risk, it is necessary to additionally control declarations and keep records of risky raw materials, products and half-products (Popov-Raljić, Blešić, 2016).

A design and equipment of production plants and hospitality kitchens - the production area, professional equipment and tools are besides the human factor one of the most common causes of cross-contamination of food in a hospitality facility. It is desirable that production parts of a facility have a physically separated area for the production of gastro-products which are labeled as safe for health / without allergens. In case there are not such conditions, it is required that the HACCP plan precisely defines procedures for cleaning and sanitation of equipment and tools used directly in the process of allergen-free gastro-products, as well as the methods of serving this type of product.

Production - a traditional way of food safety control, under the jurisdiction of state inspection authorities, was oriented to short-term goals of consumers, which is why the responsibility is nowadays transferred to the producer who must at any time document that a product is of a high quality and safe for consumer health (Popov-Raljić, 2013). The basic step is including the proscribed allergens in the HACCP plan of the production process as chemical risks in order to reduce the cross-contamination risk to a minimum, determine the plan of correct maintenance and cleaning work rooms and elements and determine the rules for storing foodstuffs that contain allergens. These procedures must especially cover the part of the production process of a product reconstruction or recycling where the foodstuffs which have been processed into half-products are after a while processed into a final product. The second step of providing production protocols is a standardization of production and their records within standardized product descriptions / recipes for food preparation in a hospitality facility. With the product 
description, allergens and allergenic food ingredientsmust be precisely defined, as well as a possibility of making a dish without allergenic ingredients with exactly signified alternatives for allergenic food ingredients.

Information for consumers and documentation-according to the Regulation on declaration, labeling and advertizing food (Pravilnik o deklarisanju, označavanju i reklamiranju hrane (,Sl.glasnik RS“ broj 19/2017) subjects in food business in all stages of the food chain are responsible for declarations if their activities include providing information about food to consumers. The subject responsible for the declaration of packaged food is the one stated on the product. For the declaration of unpackaged food, the responsible subject is the one who offers, and/or sells the product to the end consumer in the place of sale. It is very important that the information on allergens is unambiguous, readable, indelible and uncovered by other text or a picture. In hospitality facilities, the information on allergens can be expressed in: means of offer with the name of a dish and the food ingredients it contains (menus), on cards which accompany a dish in a showcase or buffet tables, on a screen or posters with a daily offer, or in standardized recipes (Aleksić, Popov-Raljić, 2015). Examples of good practice are spreadsheets (Table 2.) which provide basic information on nutritive allergens put in a visible place where they are accessible to all employees in the production part of a facility.

Table 2. An example of basic information on allergenic food ingredients contained in Gastro-products in a hospitality kitchen

\begin{tabular}{|c|c|c|c|c|c|c|c|c|c|c|c|c|c|c|c|}
\hline \multirow{2}{*}{ 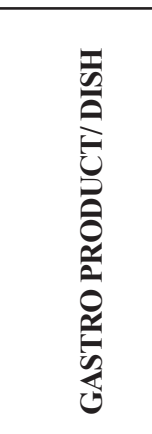 } & \multicolumn{14}{|c|}{$\begin{array}{c}\text { ALLERGEN INGREDIENTS IN GASTRO PRODUCTS / } \\
\text { DISHES }\end{array}$} & \multirow{2}{*}{ 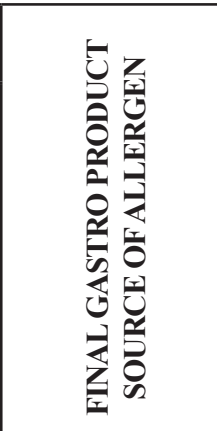 } \\
\hline & 見 & 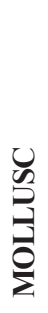 & 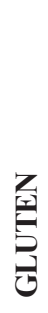 & 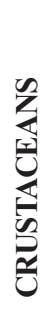 & ئ & $\mid \frac{\bar{n}}{\bar{\Omega}}$ & 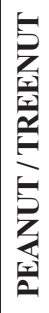 & $\stackrel{\text { 当 }}{\mathrm{E}}$ & 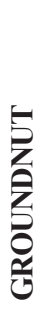 & ङ & 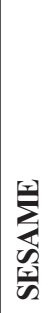 & $\frac{\partial}{\frac{1}{2}}$ & 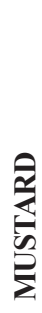 & 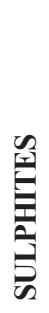 & \\
\hline $\begin{array}{l}\text { Amuse } \\
\text { bouche }\end{array}$ & & & & & & & & & & & & & & & tuna, dressing \\
\hline $\begin{array}{l}\text { Smoked } \\
\text { salmon }\end{array}$ & & & & & & & & & & & & & & & fish, prawn \\
\hline Terrine & & & & & & & & & & & & & & & brioche, pistachio \\
\hline Celery soup & & & & & & & & & & & & & & & celery, milk \\
\hline
\end{tabular}




\begin{tabular}{|c|c|c|c|c|c|c|c|c|c|c|c|c|c|c|c|}
\hline \multirow[b]{2}{*}{ 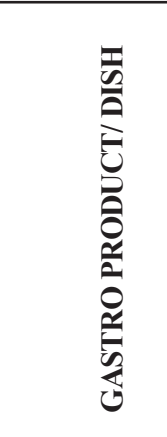 } & \multicolumn{14}{|c|}{$\begin{array}{l}\text { ALLERGEN INGREDIENTS IN } \\
\text { GASTRO PRODUCTS / DISHES }\end{array}$} & \multirow{2}{*}{ 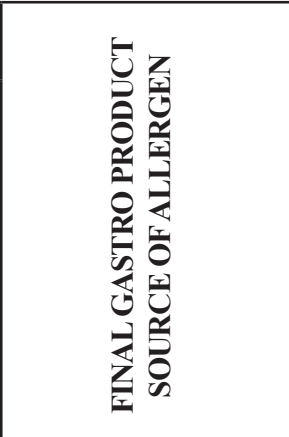 } \\
\hline & 罙 & 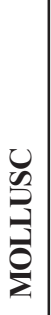 & 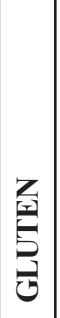 & 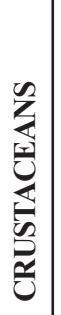 & ئ & $\mid \begin{array}{l}\overline{\mathscr{2}} \\
\frac{2}{\Sigma}\end{array}$ & 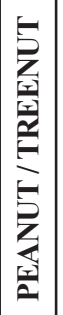 & $\stackrel{ }{\Xi}$ & 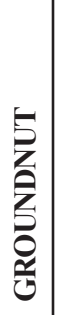 & 式 & 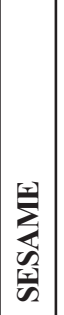 & 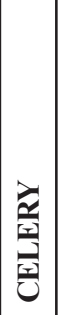 & 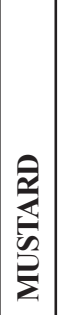 & 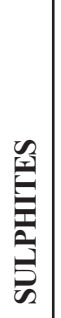 & \\
\hline Sorbet & & & & & & & & & & & & & & & popping candy, sorbet \\
\hline Beef & & & & & & & & & & & & & & & $\begin{array}{l}\text { potato puree, wine } \\
\text { sauce }\end{array}$ \\
\hline Turbut & & & & & & & & & & & & & & & fish, caviar, sauce \\
\hline Venison & & & & & & & & & & & & & & & $\begin{array}{l}\text { puree, sauce, } \\
\text { dauphinoise }\end{array}$ \\
\hline Ricotta & & & & & & & & & & & & & & & ravioli \\
\hline Pudding & & & & & & & & & & & & & & & pudding \\
\hline Creme brulee & & & & & & & & & & & & & & & brulee, biscuit \\
\hline Petit fours & & & & & & & & & & & & & & & $\begin{array}{l}\text { additive / filling and } \\
\text { topping }\end{array}$ \\
\hline & $\mathrm{CA}$ & NBE & $\angle$ SEF & RVEI & D W & ITHC & OUT & AN & ALL & UER & GEN & & & & \\
\hline & $\mathrm{CH}$ & $\overline{\text { ECK }}$ & WI & TH T & THE & $\overline{\text { GUE }}$ & EST & & & & & & & & \\
\hline & $\mathrm{CO}$ & NTA & INS & $\overline{A N A}$ & ALLI & ERG & EN & & & & & & & & \\
\hline
\end{tabular}

Source: Authors

The development of new gastronomic products and their changes - when introducing a new gastro-product/dish, it is necessary to consider whether an allergenic ingredient has a major role or whether it can be substituted, and if so, it should be stated what it can be substituted with.

\section{The importance and goals of implementing new knowledge in the field of allergenic food ingredientsrisk management}

In the field of allergenic food ingredients risk management in the food industry and hospitality, the irrational opinion of zero risk tolerance prevails, which imposes complete avoidance of any food ingredients which can be a potential allergen (Allen et al., 2014). The risk of crosscontamination with allergens in the production process exists even with the efforts of food producers to act in compliance with all requests of application of good hygienic practice principles. The predictive modeling in the allergenic food ingredients risk management is significantly made difficult because of badly defined way of labeling foodstuffs where the zero tolerance of risk of allergens imposes on the food producers to use the term "it may 
contain" when labeling food products. According to Zurzolo et al., 2013, about 65\% of food ingredients which are daily used in nutrition in Australia are labeled with a preventive phrase "it may contain". This form of labeling misleads the consumers with a food allergy problem as well as caterers who are obliged to make their gastro-product in compliance with legal regulations and needs of consumers. The need for establishing a reliable system of food declaration, labeling and advertizing caused the necessary step of science such as determining an eliciting dose / ED of allergenic food ingredientswhich can vary depending on individual predispositions and geographic determinants. For the reason of consumers' safety, the lowest doses determined by a research of a group of scientists in Allergen bureau VITAL in Australia are taken as starting eliciting doses of protein in allergenic foodstuffs. The program VITAL 2.0 (Allergen bureau, 2012) determined the reference doses of the overall intake of allergenic proteins (table 1.) and the action network of the level of risk of allergenic food ingredients is determined and it represents a ratio of reference doses and reference quantities of food intake / a gastro-product serving size for one meal.

Transition between action levels $=$

*Reference dose $x$ (1000/ *Reference quantity of intake)

* Reference dose - is a total quantity of a protein from an allergenic foodstuff which only the most sensitive portion of the allergic population reacts to $(1-5 \%)$.

*Reference quantity of intake - the total quantity of a consumed gastro-product

By determining reference doses, an effective foundation of communication within allergenic foodstuffs risk management was established, which has enabled a detailed identification, characterization and significantly facilitated risk management, pondering and choice, that is, a detailed risk analysis.

\section{Conclusion}

Basic characteristics of nutritive allergens (a large number of food ingredients containing allergens, a minimal quantity which causes a reaction, a wide range of symptoms, and a small number of people suffering from food allergies) represent a great challenge for food manufacturers in the process of making a safety management plan. Safety management of nutritive allergens has to be directed to careful risk analyses in every segment of food production and sales chain in hospitality. The guidelines that point to a potential risk must be ensured so that nutritive allergens are clearly and precisely defined or that they are not present in quantities which can jeopardize the health of consumers. They must follow all segments of food production and sales chain in a hospitality facility, from the design, through the origin of a food ingredient, declaration and labeling in the means of supply to the safe consummation of food and established responsibility.

Allergenic food ingredients and gastro-products which contain them are distinguished by specific characteristics compared to other health and safety risks. They can be controlled and reduced to a minimum with the application of developed methodologies within the context of 
other risks. The key foundation of the management of allergen safety is good communication between consumers and employees, employees and suppliers and interpersonal communication in a hospitality facility. Nevertheless, risks which are not controlled by allergen management are undeclared or wrongly declared allergens and undetermined allergies. Allergens in food ingredients which are not correctly labeled or which are pointed out in a less recognizable manner can cause significant failures in the safety management system. Another risky point which is almost impossible to avoid is an allergic reaction which has occurred for the first time. These situations require that there is a person in a hospitality facility who is trained to recognize such symptoms and react correctly and timely.

The factor which is the most difficult to control and which can significantly endanger the food safety system is a human factor. Therefore, one of the primary tasks of a hospitality facility management is providing appropriate trainings and education with the aim of raising awareness in employees of risks which can be caused by allergenic food ingredients and gastro-products.

\section{Literature}

1. Abbot, M., Byrd-Bredbenner, C., Grasso, D. (2007): Know before you serve: developing a food-allergy fact sheet, Cornell Hotel Restaurant Administration Quarterly, No. 48, pp. 274-283.

2. Ahuja, R., Sicherer, H. (2007): Food allergy management from the perspective of restaurant and food establishment personnel, Annals of Allergy, Asthma and Immunology, No. 98, pp. 344-348.

3. Alldrick, J. (2006): Managing allergy issues, Anherm Netherlands: The World of food ingredients, (October/November), pp. 64-65.

4. Allen, K.J., Remington, B.C., Baumert, J.L., Crevel, R.W.R., Houben, G.F., BrookeTaylor, S., Kruizinga, A.G., Taylor, S.L. (2014): Allergen reference doses for precautionary labeling (VITAL 2.0): clinical implications, Journal of Allergy and Clinical Immunology, Vol. 133, No.1, pp. 156-164.

5. Aleksić M., Popov-Raljić J. (2015): Alergeni kao hemijski rizici u sistemu bezbednosti hrane i njihovo označavanje, Hotellink, Visoka hotelijerska škola, Beograd, Srbija.

6. Allergen bureau (2012): Informing the food industry VITAL 2.0-what you need to know. Allergen bureau Australia and New Zealand.

7. Branum, M., Lukacs, S. (2008): Food Allergy Among US Children: Trends in Prevalence and Hospitalizations, National Center for Health Statistics, Hyattsville, MD.

8. Choi, H., Rajagopal, L. (2013): Food allergy knowledge, attitudes, practices, and training of foodservice workers at a university foodservice operation in the Midwestern United States, Food Control, No. 31, pp. 474481.

9. De Blok, M., Vlieg-Boerstra, J., Oude Elberink, G., Duiverman, J., Galvin, A., Hourihane, B., Cornelisse-Vermaat, R., Frewer, L., Mills, C., Dubois, E. (2007): A framework for measuring thesocial impact of food allergy across Europe: a EuroPrevall state of the art paper, Allergy, No. 62, pp. 733-737.

10. Dupuis, R., Meisel, Z., Grande, D., Strupp, E., Kounaves, S., Graves, A., Frasso, R., 
Cannuscio, C. (2016): Food allergy management among restaurant workers in a large U.S. city, Food Control, No. 63, pp. 147-157.

11. Fooddrink Europe (2013): Guidance on Food Allergen Management for Food Manufacturers.

12. Hattersley, S., Ward, R., Baka, A., Crevel, R. (2014): Advances in the risk management of unintended presence of allergenic foods in manufactured food products-An overview, Food and Chemical Toxicology, No. 67, pp. 255-261.

13. Kroes, R., Galli, C., Munro, I., Schilter, B., Tran, L., Walker Würtzen, G. (2000): Threshold of toxicological concern for chemical substances present in the diet: a practical tool for assessing the need for toxicity testing, Food Chemical Toxicology, No. 38, pp. 255-312.

14. Kwon, J., Sauer, L., Wen, H., Bisges, E., Myers, L. (2013): Dining experiences of customers with food allergies, In: Poster Presented at the Food and NutritionConference and Expo (FNCE), Houston, Texas.

15. Lee, Y.M., Sozen, E. (2016): Food allergy knowledge and training among restaurant employees, International Journal of Hospitality Management, No.57, pp. 52-59.

16. Madsen, B., Hattersley, S. Buck, J., Gendel, M., Houben, G., Hourihane, J., Mackie, A., Mills, N., Norhede, P., Taylor, S., Crevel, R. (2009): Approaches to risk assessment in food allergy: Report from a workshop "developing a framework for assessing the risk from allergenic foods", Food and Chemical Toxicology, No. 47, pp. 480-489.

17. Madsen, B., Hattersley, S., Allen, J., Beyer, K., Chan, H., Godefroy, B., Hodgson, R., Mills, N., Muñoz-Furlong, A., Schnadt, S., Ward, R., Wickman, M., Crevel R. (2012): Can we define a tolerable level of risk in food allergy? Report from aEuroPrevall/UK Food Standards Agency workshop, Clinical and Experimental Allergy, No. 42, pp. 30-37.

18. Mandabach, H., Ellsworth, A., Vanleeuwen, M., Blanch, G., Waters, L. (2005): Restaurant managers 'knowledge of food allergies: a comparison of differencesby chain or independent affiliation, type of service and size. Science Technology, Vol. 4, No. 2-3, pp. 63-77.

19. Popov-Raljić J. (2013): Senzorna analiza hrane i pića, Univerzitet u Novom Sadu, Prirodno-matematički fakultet, Departman za geografiju, turizam i hotelijerstvo, Novi Sad, Srbija.

20. Popov-Raljić, J., Blešić, I. (2016): Bezbednost hrane - primena HACCP sistema u ugostiteljstvu i hotelijerstvu, Univerzitet u Novom Sadu, Prirodno-matematički fakultet, Departman za geografiju, turizam i hotelijerstvo, Novi Sad, Srbija.

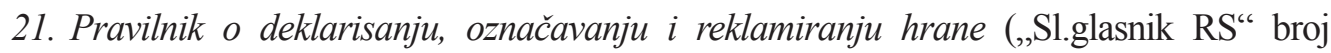
19/2017).

22. Zurzolo, A., Mathai, L., Koplin, J., Allen, J. (2012): Hidden allergens in foods and implications for labelling and clinical care of food allergic patients, Curr Allergy Asthma Report, No.12, pp. 292-296.

23. Zurzolo, G., Koplin, J., Mathai, M., Taylor, S., Tey, D., Allen, K. (2013): Foods with precautionary allergen labeling in Australia rarely contain detectable allergen. Clinical Communications, No. 4, pp. 401-403.

EP 2017 (64) 3 (1263-1276) 


\title{
UPRAVLJANJE RIZICIMAALERGENIH NAMIRNICA U UGOSTITELJSTVU ${ }^{7}$
}

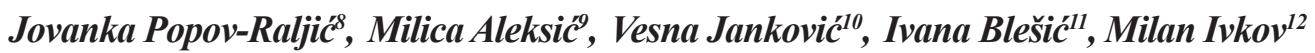

\section{Rezime}

Nutritivni alergeni pojavili su se u poslednje dve decenije kao prikriven oblik pretnje koja bitno ugrožava javno zdravlje a njihovo označavanje $i$ deklarisanje na prehrambenim proizvodima, piću i neupakovanim gastronomskim proizvodimajasnoje definisano zakonskim regulativama.

U praksi menadžment hemijskih rizika suočen je sa više neočekivanih problema. Neki od njih su: hrana na čijoj je deklaraciji ili izjavi o alergnskim sastojcima, nutritivni alergen označen neuobičajenim imenom ili slični proizvodi različitih proizvođača od kojih jedan bezbedan a drugi sadrži alergen.

Ugostiteljski objekat koji se bavi proizvodnjom i distribucijom neupakovane hrane trebalo bi da osim razvijenog HACCP koncepta $i$ standardizovanih receptura za pripremu hrane obezbedi detaljan, precizan i jasno definisan plan menadžmenta hemijskim rizicima.

Ključne reči: Alergene namirnice, menadžment rizicima, ugostiteljstvo, bezbednost hrane

7 Ovaj rad je deo kratkoročnog projekta Pokrajine Vojvodine, Novi Sad, pod nazivom: Poljoprivredni, prehrambeni i gastro proizvodi u funkciji razvoja turizma u Vojvodini usmereni na autentičnu, zdravu i bezbednu hranu pod brojem: 142-451-2669/2017.

8 Redovni professor, dr Jovanka Popov-Raljić, Univerzitet u Novom Sadu, Prirodno-matematički fakultet, Departman za geografiju, turizam i hotelijerstvo, Trg Dositeja Obradovića br. 3. 21000 Novi Sad, Srbija, Telefon: +381214852884 E-mail: jovankaraljicpopov@gmail.com

9 Milica Aleksić M.A., Asistent, Univerzitet u Novom Sadu, Prirodno-matematički fakultet, Departman za geografiju, turizam i hotelijerstvo, Trg Dositeja Obradovića br. 3. 21000 Novi Sad, Srbija, Telefon: +38121 485 2884, E-mail: aleksic.milica75@gmail.com

10 Vesna Janković, Institut za higijenu i tehnologiju mesa (INMES), Odsek za mikrobiološka i molekularno-biološka istraživanja, Ulica Kacanskog br. 13, Beograd, Srbija, Telefon: +381 112650 655, E-mail: vesna.jankovic@inmes.rs

11 Vanredni profesor, dr Ivana Blešić, Univerzitet u Novom Sadu, Prirodno-matematički fakultet, Departman za geografiju, turizam i hotelijerstvo, Trg Dositeja Obradovića br. 3. 21000 Novi Sad, Srbija, Telefon: +381 21 485 2884, E-mail: ivana.blesic@gmail.com

12 Dr Milan Ivkov, Univerzitet u Novom Sadu, Prirodno-matematički fakultet, departman za geografiju, turizam i hotelijerstvo, Trg Dositeja Obradovića br. 3. 21000 Novi Sad, Srbija Telefon: +381 21485 2842, E-mail: ivkov.milan@gmail.com 